\title{
Overview of precast concrete shear wall in China
}

\author{
Lei Tang \\ College of Civil Engineering, Southeast University, Nanjing 210096, China. \\ zzfking2210@163.com
}

Keywords: precast concrete, shear wall, experimental research, engineering application.

\begin{abstract}
Precast concrete shear walls are capable of providing preferable lateral strength and stiffness under earthquake loading and thus they are frequently employed in the moderate and high seismic risk regions. Guided by the building industrialization advocated by the government of China, domestic scientific research institutions and construction enterprises have carried out a large number of basic experimental and theoretical researches on precast concrete shear walls, especially emphasizing the horizontal connections between upper and lower precast shear wall panels. Meanwhile, numerous attempts to apply precast concrete shear wall structure was conducted in China. In this paper, the research and application progress of precast concrete shear wall in China were summarized and the key problems existing in the development of precast concrete shear wall in China were also presented.
\end{abstract}

\section{Introduction}

Due to its improved quality, lower production costs, and faster construction, precast concrete shear wall has been widely used all over the world [1,2]. Extensive research and application work has been proceeded to develop reliable connection technology for precast concrete shear wall components. In recent years, more and more attentions have been paid on the precast concrete shear wall under the guideline of building industrialization promoted as the development goal of construction industry. Representative experimental research works and engineering application projects were provided in this paper and surviving problem hindering the development of precast concrete shear wall was also indicated.

\section{Overseas Study}

It was relatively earlier for America to research on the precast concrete shear wall panel system and relevant experimental and theoretical work had been done on the horizontal connection configuration, connection property, and whole performance for the precast concrete shear wall. Khaled A. Soudki, Sami H. Rizkalla,and Bill LeBlanc [3] connected the upper and lower precast shear wall panels by several methods, such as welded steel angel, mild steel bars protruded from the lower pannel and then anchored in grouted sleeves embeded in the upper panel, shear keys, and bolted steel tube. The test results showed several useful conclusions. Welded steel angel and grouted mild steel bars were able to provide sufficient strength, ductility, and energy-dissipation capacity. The presence of shear keys could enhance the connection strength, while reduce the ductility and energy-dissipation capacity for brittle failure of shear keys. The steel tube was liable to buckling and the bolted connection performed unstablely. In addition, partially debond of grouted steel bars near the horizontal connections could reduce the stress intensity of the bars, delay yielding of the bars, and thus improve the deformability, ductility, and energy-dissipation capacity of the connection. While the strength of the connection was obviouly affected by the debond configuration of the mild steel bars.

Subsequent research work to discover the mechanical behavior and the impact on the strength, stiffness, and ductility brought about from connecting mild steel bars, shear keys, and prestressed steel was carried out. Khaled A. Soudki, Jeffrey S. West, Sami H. Rizkalla, Bruce Blackett [4] designed friction connection resisting lateral force by interface friction between precast components, 
mild steel connection, prestressed connection using prestessed strands or bars according to frequently-used connection methods in the engineering projects and studied the force property and integrity under the cyclic shear loading. The friction connection could provide limited strength, but poor stiffness. Shear keys could produce maximum lateral resistant strength among several connections, which was approximately 4 times that of friction connection, however, the strength degradated suddenly when the loading enlarged into peak force and the connection damaged brittlely. Mild steel connection was capable of developing the stength and plasticity of the mild steel and possessed favorable property. Prestessed connection could enhanced the strength due to the presence of prestressed strands or bars, while weakened the deformability, ductility, and energy-dissipating capacity resulted from the material elasticity of the prestressed steel.

\section{Domestic Study}

Several dispersive research work had been done on the precast concrete shear wall at the early stage. Sun Weiwei [5] and Liu Hua [6] prefabricated precast assembles made up of prestressed precast concrete shear walls and coupling beams. The coupling beams were connected to the shear wall by unbonded prestressed strands and remained elasic during the test. The plastic deformatoin occourred only at the joints between the shear wall and the beam. The residual displacement of the assemble was relatively small and exhibited evident self-centering capacity.

In recent years, under the pressure of environmental pollution, resource waste, and construction demand, building industrialization has been advocated in China. Therefore, several leading enterprises have accessed into this region and bring in various precast concrete shear wall technologies.

Vanke Group imports precast concrete and precast concrete form technology from Japan. It united Tongji University and Tsinghua University to do research on the technology. The junction surface between precast and cast-in-place concrete was effective througout the experiment. The precast and cast-in-place concrete worked as an integrity. The structural configuration and strengthening measurement were efficient to guarantee the integrality of the precast components connected by cast-in-place concrete and bar splices. [7]

Double-Wall Precast Concrete Building System and relevant production equipments were introduced by Sievert Group in Hefei, Anhui. It combined HeFei University of Technology to study the seismic behavior, restoring force model, and in-plane strength capacity design method of the technology.[8]

Zhongnan Group brings in new bar splice technology from Australia in which the steel bar is anchored in grouted metal bellows embedded in the precast wall panel and thus the grouted bar and embedded bar form a lap joint. It united Southeast University to discover the seismic behavior and seek configuration improvement of the technology according to the chinese code requirements. $[9,10,11]$

In conclusion, precast concrete shear wall emulating monolithic cast-in-place shear wall has been accepted and energetically developed in our country. The important specification 'Technical specification for precast concrete structures' [12] has been released and will guide the development of the precast concrete structures.

\section{Domestic Engineering Projects}

Vanke Group has invested massive funds and established several National housing industrialization bases to develop the precast concrete technology. Several typical precast concrete pilot projects using precast and precast form technology were constructed to examine the technology. The two completed residence projects of 18-story height in Shanghai and one on-going residence project of 30-story height in Suzhou are all pioneer attempts in China. 
Double wall system is introduced later and its application is thus restricted. Meanwhile, due to the code requirements in China, the applicable range is also limited. It is usually applied in the underground garage structure.

The technology brought in by Zhongnan Group was applied relatively wildly. Due to the essence of lap splice, its applicable structural heght is restricted and its pilot projects mainly in Haimen and Shengyang are almost within the range of 10 stories.

\section{Summary and Problems}

The precast concrete shear wall has been quickly developed in China. However, it is still premature and its applicable range is restricted, limiting its further development. Several aspects of key problems need to be furtherly studied:

(1) The uniform precast concrete shear wall structure system and assorted structural connection configuration should be developed, and

(2) The standardized and modulated precast component system should be established, and

(3) The standard construction technology and simple measurement technique should be developed.

\section{References}

[1] Yee A A. Social and environmental benefits of precast concrete technology [J]. PCI Journal, 2001, 46 (3): 14-19.

[2] Yee A A. Structural and economic benefits of precast/prestressed concrete construction [J]. PCI Journal, 2001, 46 (3): 34-42.

[3] Khaled A. Soudki, Sami H. Rizkalla, Bill LeBlanc. Horizontal Connections for Precast Concrete Shear Walls Subjected to Cyclic Deformations Part 1: Mild Steel Connections [J]. PCI Journal, 1995, V. 40, No. 4 (July-August): pp. 78-96.

[4] Khaled A. Soudki, Jeffrey S. West, Sami H. Rizkalla, Bruce Blackett. Horizontal Connections for Precast Concrete Shear Wall Panels under Cyclic Shear Loading. PCI Journal, 1996, V. 41, No. 3 (May-June):pp. 64-81.

[5] Sun Weiwei. Study on Seismic Capacity and Design Method of Unbonded Post-tensioned Short-pier Wall [D]. Nanjing, Southeast University, 2006. (in Chinese)

[6] Liu Hua. Experimental Study on Seismic Behavior of Precast Post-tensioned Short-pier Wall [D]. Yangzhou, Yangzhou University, 2007. (in Chinese)

[7] Tongji University. The experimental report on precast concrete shear wall by Vanke [R]. 2010. (in Chinese)

[8] Lianxing, Ye Xianguo, Zhang Lijun, etc. Finite element analysis of the superimposed slab shear walls [J]. JOURNAL OF HEFEI UNIVERSITY OF TECHNOLOGY, 2009,32(7): 1065-1068. (in Chinese)

[9] Zhang Jun, Hou Haiquan, Dong Niancai,etc. Design and Application of Assembly Integral Shear Wall Resistance with Prefabricated Reinforved Concrete[J]. CONSTRUCTION TECHNOLOGY, 2009, 38(5): 22-24. (in Chinese)

[10]LIU Xiao-nan, GUO Zheng-xing, DONG Nian-cai,etc. Experimental Research on Behaviour of Joints of Fully Precast Assembled Shear Wall Structure[J]. JIANGSU CONSTRUCTION, 2010, (133):21-24. (in Chinese)

[11] CHEN Yao-gang. RESEARCH ON INDUSTRIALIZED FULLY-PREFABRICATED ASSEMBLY INTEGRAL SHEAR WALL SRUCTURE SYSTEM NODES[J]. Architecture Technology, 2010,41(2): 153-156. (in Chinese) 
[12]. JGJ 1-2014. Technical specification for precast concrete structures [S]. Beijing: China Architecture \& Building Press, 2014. (in Chinese) 